This is a preprint version. The final article has been published in Applied Clay Science by Elsevier.

Final version: https://www.sciencedirect.com/science/article/abs/pii/s0169131719304776

Cultrone, G. \& Carrillo-Rosúa, J. (2020). Growth of metastable phases during brick firing: Mineralogical and microtextural changes induced by the composition of the raw material and the presence of additives.

Applied Clay Science, 185. https://doi.org/10.1016/j.clay.2019.105419

\title{
Growth of metastable phases during brick firing: mineralogical and microtextural changes induced by the composition of the raw material and the presence of additives
}

\author{
Giuseppe Cultrone ${ }^{\mathrm{a}^{*}}$, Javier Carrillo-Rosúa ${ }^{\mathrm{b}, \mathrm{c}}$ \\ ${ }^{a}$ Departamento de Mineralogía y Petrología, Facultad de Ciencias, Universidad de Granada, \\ 18002 Granada, Spain \\ ${ }^{b}$ Departamento de Didáctica de las Ciencias Experimentales, Facultad de Ciencias de la \\ Educación, Universidad de Granada, 18071 Granada, Spain. \\ ${ }^{c}$ Instituto Andaluz de Ciencias de la Tierra (UGR-CSIC). Avda. de las Palmeras $N^{o}$ 4, 18100 \\ Armilla (Granada, Spain) \\ * Corresponding author. E mail address: cultrone @ugr.es (G. Cultrone)
}

\begin{abstract}
Mineralogical and textural changes experienced by solid bricks made without additives and others made with added halite or with added calcined diatomite sludge, and fired in an electric oven at 800,950 and $1100^{\circ} \mathrm{C}$ have been studied. Different analytical techniques (x-ray fluorescence, thermogravimetric analysis, x-ray diffraction, polarized optical microscopy and scanning electron microscopy) were used to reconstruct the changes that took place inside the bricks from a mineralogical and textural point of view. These changes are similar to those that take place in nature during pyrometamorphism. Carbonates decompose and react with silicates to form gehlenite, diopside and wollastonite. Plagioclase enriches in calcium and quartz concentration diminishes. Clay minerals favour the melting of matrix and the appearance of mullite. KFeldspar changes from microcline to sanidine. The extent of vitrification increases in line with the increase in the firing temperature. When halite is added, new silicates appear earlier at lower firing temperatures and molysite is formed. Calcined diatomite sludge contains cristobalite, which becomes part of the mineralogy of the bricks. The newly-formed phases contain certain chemical elements that are not normally found in their standard chemical composition.
\end{abstract}

Keywords: bricks; calcined diatomite sludge; halite; minerals reactions.

\section{Highlights}

* To study the process of formation of metastable mineral phases which develop at high temperature and atmospheric pressure

* To observe the morphology of newly-formed crystals and determine their composition and how they are influenced by the rapid firing of bricks

* To assess the influence of calcined diatomite sludge and halite in the formation of new mineral phases and changes in the texture of bricks 


\section{Introduction}

Conventional brick is one of the oldest building materials in the world and one of the most frequently used over the course of history due to its great resistance and durability (Fernandes et al., 2010). Brick constructions can be found all over the world due to the abundance on the Earth's surface of clay, the raw material used in the manufacture of bricks. Brick production process has hardly changed over the course of time and consists basically in kneading the clayey earth with water so as to work it into the right shape; it is then left to dry before being fired. What has changed in recent times is the increasingly strict control of all aspects of the manufacturing process (selection of raw materials, the addition of grogs, melting agents and additives, the process of moulding the unfired pieces, the types of kilns), so transforming the manufacture of bricks from an art into a science, thus guaranteeing a much more uniform, standardized product (Shakir \& Mohammed, 2013). However, it is not hard to find bricks which begin to deteriorate just a few years after being used in a building, due to some failure in the production process (Cerdeño del Castillo et al., 2000). A careful selection of the raw materials and strict control of all phases of the production process are essential for obtaining high-quality bricks and other ceramic products.

In spite of the widespread use of bricks in our society, Parsons (2014) highlights the fact that there are fewer bibliographic references than one might expect about the mineralogical changes that take place in raw materials during firing. The dynamics of reactions between the mineral phases during the firing of bricks have yet to be fully studied, bearing in mind the large number of variables that come into play during this process. These include, for example, differences in the composition of raw materials, the presence or absence of additives, firing temperatures and oxidation or reduction conditions inside the kiln (Brownell, 1976).

A wide variety of additives can be added to the clay used in brick production process. These additives have a range of different purposes, seeking above all to improve the physical and mechanical properties of bricks. Most of additives are waste products from industrial activities, which means that they also provide a solution to environmental problems by eliminating products that could be potentially damaging for human health. These include substances of plant origin such as carbon (Phonphuak \& Thiansem, 2012), sawdust (Demir, 2008), olive pomace (La Rubia García et al., 2012), wheat straw (Bories et al., 2015) and paper residues (Sutcu et al., 2014; Martínez et al., 2012; Demir et al., 2005), which are added, for example, to increase the porosity or thermal insulation while trying to maintain good mechanical properties. Research has also been done on the addition of inorganic waste materials such as the sludge that accumulates in granite (Hojamberdiev et al., 2011) and marble quarries (Sutcu et al., 2015; Bilgin et al., 2012) and which enhances the development of new mineral phases after the pieces have been fired. Other examples include common glass (Kazmi et al., 2018), which improves the compactness of the bricks, and the fly ash produced during the combustion processes at electricity power plants (Leiva et al., 2016; Pérez Villarejo et al., 2012; Fernández Pereira et al., 2011; Koseoglu et al., 2010; Abbas et al., 2017; Lingling et al., 2005), which reduces the density of the bricks. Other research has centred on the ash from incineration of urban solid wastes, which are rich in heavy metals. When used as additives in brick manufacturing process, these toxic substances are sealed inside the bricks, so reducing the possibility of leaching into the environment (Zhang \& Qi, 2012).Recent review articles (with extensive bibliography) about the use of additives to increase the technical quality of bricks have been published by Zhang (2013), Bories et al. (2014), Muñoz Velasco et al. (2014), Monteiro \& Fontes Vieira (2014) and Al Fakih et al. (2019). Unfortunately, almost all of these are one-off, isolated studies with promising results but which have not been applied in large-scale brick production.

In this paper, the addition of two very different products in terms of origin and composition are analysed, which have hitherto not been studied from the perspective taken in this article. These products are firstly, calcined diatomite sludge with traces of yeast and secondly, halite. The objective of this paper is to assess the mineralogical and textural changes that take place in bricks made with clayey earth that is rich in carbonates and sulphates, so revealing how the differences induced by the presence of these additives can influence the formation of new mineral phases, the textural evolution of the bricks and the degree of vitrification.

Diatomite is a sedimentary rock which is formed by the accumulation of skeletons of diatoms, unicellular marine algae. In mineralogical terms it is composed of amorphous silica (generally opal). Diatomite is widely used in industry as an abrasive, in the manufacture of insulation bricks and above all in the filtration of wine, beer and other alcoholic substances to give them a crystalline appearance (Galán et al., 1993; Hadjar et al., 2008; Gómez et al., 2015, Matsunaga et al., 2017). In this case the diatomite is calcined so as to eliminate any possible organic remains. After calcination, the amorphous silica is converted into cristobalite. This transformation takes place at $1000{ }^{\circ} \mathrm{C}$ or at almost $800{ }^{\circ} \mathrm{C}$ if $\mathrm{Na} 2 \mathrm{CO} 3$ is added as melting agent (Ediz et 
al., 2010). The $\mathrm{Na}+$ ions in this carbonate partially break the Si-O-Si chains in the opal, so accelerating its transformation into cristobalite (Zheng et al., 2018). In the specific case of beer, the diatomite traps the yeast used in the fermentation process and other organic particles(barley, corn) which may remain in the liquid. So far no-one has discovered a way of reusing calcined diatomite sludge with yeast, and it is normally disposed of "as is", so creating a waste management problem. The bibliography on the addition of natural or calcined diatomite with or without other additives in bricks is quite limited (Galán Arboledas et al., 2017; Man et al., 2017) and does not provide information about the mineralogical changes that take place inside these bricks. Bearing in mind the very low weight per unit of volume of calcined diatomite with yeast, in this paper $10 \%$ in weight of this additive to the clayey earth was added.

Halite has even more applications ranging from its use in the food sector as a condiment or preservative to its industrial applications in the production of hydrochloric acid and sodium carbonate. Ancient civilizations noticed some improvements in ceramic production after the clayey earths were kneaded with seawater (Rye, 1976). This is probably due to the fact that halite acts as melting agent at low firing temperatures (Cultrone et al., 2005). In addition, Laird and Worcester (1956) observed that the addition of $0.5-1 \%$ common salt can inhibit lime-blowing, a problem that arises due to the presence of carbonates in the raw materials. In spite of this, little research has been done on the effects produced by this salt in the firing of bricks or on the mineralogical and textural changes that take place. In this study, $30 \%$ in weight of halite to the kneading water was added. This concentration is considerably higher than the concentration of this salt in seawater. In this way, possible differences in the mineralogical and textural changes that take place during firing compared to bricks made without additives will be highlighted.

If we can better understand the mineralogical and textural transformations that take place in bricks with and without additives (in this case halite and calcined diatomite sludge with yeast), this will give us a better understanding of the brick productionprocess. These transformations are also closely related with contact metamorphism, as both processes tend to reach balanced situations of high temperatures and low pressure and produce similar sets of high-temperature minerals (Grapes, 2005).

\section{Methodology}

The raw material selected for making the bricks comes from a quarry in the village of Jun, about $5 \mathrm{~km}$ north of Granada (Spain). It is a grey clay from the Messinian Age, which locally presents bands of micaceous silts and sands. Occasionally, the clays are interspersed with gypsums and carbonates that are rich in gastropods. This would suggest the establishment of a lacustrine environment and the continentalization of the intermountain depression of Granada (Lupiani Moreno and Soria Mingorance, 1988).

In the first stage of brick manufacturing process the largest fragments, including gypsum crystals and rock fragments, were eliminated from the clayey earth. Then the earth was sieved, discarding the fraction measuring over $1.5 \mathrm{~mm}$. Bricks were made manually, by adding the necessary amount of water to the sieved clay to make it workable. Approximately $500 \mathrm{~mL}$ of water per kilogram of clay was required. The paste was then placed in a moistened wooden mould measuring $15 \times 20 \times 4 \mathrm{~cm} 3$ and pressed down initially with the palm of the hand and later with a roller to compact it and eliminate any excess air. The surface of the paste was smoothed down with a moistened plastic ruler. After an hour, the brick was removed from the mould and cut into $4 \mathrm{~cm}$-edge cubes using tensor wire. Cubes were stored in the laboratory at $25^{\circ} \mathrm{C}$ and $35 \%$ relative humidity and took about a week to dry out. Bricks made with diatomite sludge (10\% in weight) and halite (30\% in weight) needed about the same amount of water for kneading purposes and the same procedure was followed as for making the bricks without additives. The dried unfired bricks were then fired in a Herotec CR-35 electrickiln with a fixed heat source at the following temperatures: 800,950 and $1100{ }^{\circ} \mathrm{C}$. $950{ }^{\circ} \mathrm{C}$ is one of the most commonly used temperatures in brick production. The other two firing temperatures, one lower than $950{ }^{\circ} \mathrm{C}$ and the other higher, were chosen to study the changes that take place in the mineralogy and the texture of bricks over a $300{ }^{\circ} \mathrm{C}$ temperature range. The temperature inside the kiln was kept constant at $100{ }^{\circ} \mathrm{C}$ for 1 hour to ensure that there was no moisture left in any of the samples. Samples were then heated up to the selected firing temperature at a heating speed of $2{ }^{\circ} \mathrm{C} / \mathrm{min}$. Once this temperature had been reached, it was maintained for 3 hours. Finally, bricks were left to cool inside the kiln until the next day, with the whole firing-cooling process taking about 24 hours. 9 different types of bricks were prepared, combining each of the three variables (no additives, added halite, added calcined diatomite 
sludge) and each of the three firing temperatures. Table 1 shows the abbreviation and the composition for each sample.

In macroscopic terms, bricks acquired an orangey colour after firing, which turned a little darker at $1100^{\circ} \mathrm{C}$. Bricks made with added halite acquired a slightly lighter tone, and some circular or oval-shaped yellow stains could be observed at $950{ }^{\circ} \mathrm{C}$ and $1100{ }^{\circ} \mathrm{C}$. These stains were up to $5 \mathrm{~mm}$ long and covered the surfaces of bricks.

The chemistry of the raw material was determined by X-ray fluorescence (XRF) using a PANalytical Zetium compact spectrometer with a $\mathrm{Rh}$ anode and $4 \mathrm{kV}$ X-ray generator. $6 \mathrm{~g}$ per sample were milled to powder in an agate mortar and then analysed.

The mineralogical composition of the raw material, of the calcined diatomite sludge with yeast and of the fired bricks was determined by means of powder X-ray diffraction (PXRD) using a PANalytical X'Pert PRO diffractometer. The working conditions were: $\mathrm{CuK} \alpha$ radiation $(\lambda=1.5405 \AA), 45 \mathrm{kV}$ voltage, $40 \mathrm{~mA}$ current, 3 to $60^{\circ} 2 \theta$ explored area and $0.012 \theta / \mathrm{s}$ goniometer speed. Samples were milled in an agate mortar to a particle size of less than $0.053 \mathrm{~mm}$ and then analysed. The interpretation of diffractograms was carried out using the XPowderX software (Martin, 2016). Quantitative analysis of the mineral phases was performed using the non-linear least square method to fit full-profile diffractograms and the results were compared with standard values recorded in the American Mineralogist Crystal Structure Database (AMCSD). This database and the Pattern Intensity Ratio (PIR) were also used to obtain an indicative value of the amorphous versus crystalline phases $(\mathrm{a} / \mathrm{c})$ ratio. This ratio is based on the mean value of the intensities, standard deviation and area of the crystal reflection (Martín, 2016).

Thermogravimetric (TG) analysis was used to study the thermal decomposition of the clayey earth so as to complete the information obtained by PXRD. TG analysis was performed with a Mettler-Toledo TGA/DSC1 in $\mathrm{N} 2$ atmosphere $(20 \mathrm{ml} / \mathrm{min})$ and flushed-air atmosphere $(50 \mathrm{ml} / \mathrm{min})$ at a heating rate of $20^{\circ} \mathrm{C} / \mathrm{min}$ and a 25-950 ${ }^{\circ} \mathrm{C}$ temperature interval.

The microscopic identification of the mineral phases and the texture of bricks was performed by observing polished thin sections under a Carl Zeiss Jenapol-U polarized optical microscopy (POM) coupled with a Nikon D7000 digital microphotography unit. The microstructural characterization of bricks, the observation of reaction rims where new mineral phases were developing, changes in the pore system and the development of vitreous phase upon firing were studied by observing polished carbon-coated thin sections using two high-resolution scanning electron microscopes. One was a field emission scanning electron microscope with a focused ion beam (FIB-FESEM) Carl Zeiss STM (AURIGA Series), and the other was a variable pressure scanning electron microscope (VPSEM) Zeiss SUPRA40VP, both coupled with EDX microanalysis.

\section{Results and discussion}

\subsection{Raw material chemistry by XRF}

The clayey earth is composed above all of silica (about 50\%) and has significant concentrations of alumina, suggesting the presence of aluminosilicates (Table 2). The calcium content is well above $6 \%$, which means that the raw material can be classified as calcareous (Maniatis \& Tite, 1981). The Fe content is just over 5\%. The loss on ignition (LOI, Table 2) was almost $12 \%$ and may be due to the combustion of organic matter and the decomposition of carbonates, phyllosilicates and gypsum.

\subsection{Raw material mineralogy by $P X R D$ and $T G$}

According to PXRD data, the clayey earth is made up above all of quartz, feldspars s.l. and phyllosilicates and small quantities of calcite, dolomite and gypsum. Feldspars s.l. are composed of andesine-type plagioclase and microcline while phyllosilicates are made up above all of illite/muscovite and smaller concentrations of paragonite, smectites, chlorite and kaolinite (Fig 1a). The diatomite sludge is mainly composed of phases of silica, cristobalite and, to a lesser extent, quartz. Another phase detected was the anorthite-type plagioclase (Fig. 1b). 
Figure 2 shows the results of the thermogravimetric analysis of the clayey earth. This presents an initial weight loss of $2 \%$ at around $100{ }^{\circ} \mathrm{C}$, which is probably due to the process of dehydration of the gypsum and its transformation into anhydrite.

A slight but constant weight loss of $1 \%$ between $200{ }^{\circ} \mathrm{C}$ and $400{ }^{\circ} \mathrm{C}$ approximately was then observed, with a point of inflection at $287^{\circ} \mathrm{C}$, which is related to the combustion of different types of organic matter present in the soil (Guo et al., 2016). A further weight loss of $1 \%$ can be observed around $520{ }^{\circ} \mathrm{C}$ due to the dehydroxylation of phyllosilicates. The greatest weight loss, of $11 \%$, can be seen between 600 and $800{ }^{\circ} \mathrm{C}$ due to the decomposition of carbonates and the resulting release of $\mathrm{CO} 2$ and further loss ofhydroxyls (OH-) from the phyllosilicates. It is also worth noting that between 800 and $950{ }^{\circ} \mathrm{C}$ there is an additional slight weight loss $(0.5 \%)$ owing to the continuing decomposition of $\mathrm{OH}$ - of the phyllosilicates. It is important to remember that of the various phyllosilicates identified in the clayey earth (Fig. 1a), smectites, chlorite, kaolinite and paragonite dehydroxylate earlier than muscovite (Guggenheim, 1987).

\subsection{Brick mineralogy by PXRD}

The mineralogy of bricks according to their composition and firing temperature, as assessed by PXRD, is shown in Table 3.

In bricks made without additives and fired at $800{ }^{\circ} \mathrm{C}$ the predominant mineral phase is quartz (Table 3). Phyllosilicates are composed of illite/muscovite and smaller concentrations of paragonite. Calcite is still present at this temperature. As regards the feldspars s.l., microcline has been transformed into orthoclase, which is the most stable polymorph at $800{ }^{\circ} \mathrm{C}$. Anhydrite was also identified from the decomposition of gypsum (loss of $\mathrm{H}_{2} \mathrm{O}$ ), which was present in the raw material. At $950{ }^{\circ} \mathrm{C}$ calcite has disappeared (Table 3). According to Rodriguez Navarro et al. (2009) this carbonate begins to decompose at $600{ }^{\circ} \mathrm{C}$ and the process is completed around $850{ }^{\circ} \mathrm{C}$. The decomposition releases $\mathrm{CO} 2$ and the calcium oxide reacts with silicates to produce new mineral phases. One example is gehlenite, which is formed by the reaction between illite/muscovite, calcite and quartz as follows:

illite/muscovite calcite quartz gehlenite sanidine

$2 \mathrm{KAl}_{2}\left(\mathrm{Si}_{3} \mathrm{Al}\right) \mathrm{O}_{10}(\mathrm{OH})_{2}+2 \mathrm{CaCO}_{3}+\mathrm{SiO}_{2} \rightarrow \mathrm{Ca}_{2} \mathrm{Al}_{2} \mathrm{SiO}_{7}+\mathrm{KAlSi}_{3} \mathrm{O}_{8}+\mathrm{H}_{2} \mathrm{O}+2 \mathrm{CO}_{2}$

Plagioclase is gradually enriched in $\mathrm{Ca}$, changing from andesine to anorthite. Illite/muscovite remains involved in the formation of anorthite via its reaction with calcite and quartz:

illite/muscovite calcite quartz anorthite sanidine

$\mathrm{KAl}_{2}\left(\mathrm{Si}_{3} \mathrm{Al}\right) \mathrm{O}_{10}(\mathrm{OH})_{2}+\mathrm{CaCO}_{3}+2 \mathrm{SiO}_{2} \rightarrow \mathrm{Ca}_{2} \mathrm{Al}_{2} \mathrm{Si}_{2} \mathrm{O}_{8}+\mathrm{KAlSi}_{3} \mathrm{O}_{8}+2 \mathrm{H}_{2} \mathrm{O}+\mathrm{CO}_{2}$

After participating in reactions (1) and (2), illite/muscovite and quartz are gradually consumed and their concentrations reduce. In fact, at $950{ }^{\circ} \mathrm{C}$ quartz is no longer the main mineral phase as anorthite is present in greater concentrations (Table 3). Paragonite can no longer be identified and K-feldspar has undergone a new transformation from orthoclase to sanidine due to the increase in temperature (Table 3). More mineralogical changes take place at $1100{ }^{\circ} \mathrm{C}$ and the concentrations of newly-formed phases increase. The diffraction peaks of phyllosilicates can no longer be observed and new Ca-silicates (wollastonite) and CaMg-silicates (diopside) appear (Table 3). These are formed due to the reaction of quartz with $\mathrm{Ca}$ and $\mathrm{Mg}$ ions produced by the decomposition of calcite and dolomite as a result of the following reactions:

quartz calcite wollastonite

$\mathrm{SiO}_{2}+\mathrm{CaCO}_{3} \rightarrow \mathrm{CaSiO}_{3}+\mathrm{CO}_{2}$

quartz dolomite diopside

$2 \mathrm{SiO}_{2}+\mathrm{CaMg}\left(\mathrm{CO}_{3}\right)_{2} \rightarrow \mathrm{CaMgSi}_{2} \mathrm{O}_{6}+2 \mathrm{CO}_{2}$

One of the newly-formed phases, gehlenite, is present at $1100{ }^{\circ} \mathrm{C}$, in falling concentrations. According to Capel et al. (1985) this aluminium silicate appeared at $950{ }^{\circ} \mathrm{C}$ was consumed in part in the reaction with quartz so leading to the appearance of larger quantities of wollastonite and anorthite as follows:

quartz gehlenite wollastonite anorthite

$2 \mathrm{SiO}_{2}+\mathrm{Ca}_{2} \mathrm{Al}_{2} \mathrm{SiO}_{7} \rightarrow \mathrm{CaSiO}_{3}+\mathrm{CaAl}_{2} \mathrm{Si}_{2} \mathrm{O}_{8}$ 
In the diffractograms it is interesting to note the increase in the amorphous component with regard to the crystalline phases as the firing temperature increases (a/c Table 3), which suggests a gradual increase in the vitrification of bricks.

The addition of calcined diatomite sludge with yeast only slightly modified the mineralogy of bricks. In fact, the most significant change was the appearance of cristobalite (albeit in low concentrations), which is one of the mineralogical components of the additive. The amount of cristobalite does not remain constant and instead increases in line with increases in the firing temperature (Table 3). Zhang et al. (2005) observed an increase in cristobalite when natural diatomite was used in the production of porous bricks. However, the increase took place at higher firing temperatures (between 1150 and $1250{ }^{\circ} \mathrm{C}$ ) compared to those observed in our samples (earlier at $950^{\circ} \mathrm{C}$ ). It is highly likely that the increase in cristobalite at lower temperatures in our brick samples was due to the difference in the composition of the raw materials, the former (Zhang et al. 2005) made up almost exclusively of amorphous silica (opal) and the latter, the clayey earth from Jun, characterized by the presence of various minerals. Of the other mineral phases identified it is significant that compared to the bricks made without additives, in those made with added calcined diatomite sludge there is a considerable increase in anorthite content at $1100^{\circ} \mathrm{C}$ while quartz fell to half its previous level.

The addition of halite leads to more significant changes in the mineralogy than the addition of diatomite sludge, in that it brings forward the appearance of new mineral phases by reaction with the clay matrix thanks to its low melting point $\left(804{ }^{\circ} \mathrm{C}\right)$. Indeed, diopside and wollastonite were first identified at $950{ }^{\circ} \mathrm{C}$, while in the other types of brick they did not appear until $1100{ }^{\circ} \mathrm{C}$ (Table 3). In addition, molysite $\left(\mathrm{FeCl}_{3}\right)$ and mullite $\left(\mathrm{Al}_{6} \mathrm{Si}_{2} \mathrm{O}_{13}\right)$ only appear in bricks made with halite (Table 3). Molysite is a yellowish chloride that is usually found in volcanic fumaroles, which means that its detection in bricks is quite unusual. However, Stimmel et al. (1982) had detected its presence in bricks made by kneading clayey earths with seawater. According to these authors, during firing, sodium chloride interacts with the matrix to form $\mathrm{HCl}$. This acid comes into contact with hematite, which leads to the crystallization of iron chloride. The reaction takes place as follows:

hematite molysite

$6 \mathrm{HCl}+\mathrm{Fe}_{2} \mathrm{O}_{3} \rightarrow 2 \mathrm{FeCl}_{3}+3 \mathrm{H}_{2} \mathrm{O}$

Mullite is only identified at $1100{ }^{\circ} \mathrm{C}$. Cultrone et al. (2001) and Rodriguez Navarro et al. (2003) described the appearance of mullite due to the epitactic replacement of muscovite as a result of the following reaction:

$\begin{array}{ll}\text { illite/muscovite } & \text { sanidine mullite } \\ 3 \mathrm{KAl}_{2}\left(\mathrm{Si}_{3} \mathrm{Al}\right) \mathrm{O}_{10}(\mathrm{OH})_{2}+2 \mathrm{SiO}_{2} \rightarrow 3 \mathrm{KAlSi}_{3} \mathrm{O}_{8}+\mathrm{Al}_{6} \mathrm{Si}_{2} \mathrm{O}_{13}+3 \mathrm{H}_{2} \mathrm{O}\end{array}$

Finally, anhydrite disappears at $1100{ }^{\circ} \mathrm{C}$, something that only happens in this group of bricks, while anorthite increases more than in any other kind of bricks (reaching over $50 \%$ ).

\subsection{Brick texture by POM}

Petrographic microscope observations of bricks made without additives fired at $800{ }^{\circ} \mathrm{C}$ show that the temper is made up of metamorphic rock fragments (gneisses and to a lesser extent micaschists) of about $1 \mathrm{~mm}$ in length. Quartz also appears in isolated grains with a mosaic texture and undulose extinction. Phyllosilicates are muscovite-type with an interference colour that reaches blue of II order and normally have the same orientation due to the pressure exerted on the clay during the kneading phase (Fig. 3a). Hematite crystals and partially decomposed carbonate grains were also identified. The latter are grey in colour and have a micritic texture, completely losing their characteristic interference colour. On occasions, it is possible to observe a darker rim around these crystals. Some whitish-yellow crystals of anhydrite are dispersed within the matrix. The matrix has an orangey colour and contains elongated pores with the same orientation as the phyllosilicates. At $950{ }^{\circ} \mathrm{C}$, the matrix is less birefringent and acquires a brown hue due to an increase in the vitrification of the bricks. Carbonates are completely decomposed, the grains of anhydrite have a more fractured appearance and muscovite crystals no longer reach the same interference colours as at $800{ }^{\circ} \mathrm{C}(\mathrm{Fig}$. $3 \mathrm{~b}$ ). There is an evident separation between anhydrite grains and the matrix due to the loss of $\mathrm{H} 2 \mathrm{O}$ during the transformation of gypsum into anhydrite. At $1100{ }^{\circ} \mathrm{C}$ the most clearly distinguishable features are the quartz grains, which seem to be smaller than those in bricks fired at lower temperatures (Fig. 3c). In addition to quartz, some iron oxides and some small light grey pseudomorphs of phyllosilicates were also identified. The 
matrix is dark and has a very uniform appearance, which indicates that brick is highly vitrified. Pores have become more rounded or oval-shaped.

No substantial differences could be observed between the bricks made with diatomite sludge and those made with no additives. Calcite crystals have disappeared at $1100{ }^{\circ} \mathrm{C}$ leaving pores in their places. In a few cases, greyish heavily fractured fragments of the former carbonates remain (Fig. 3d). Halite makes the bricks lighter, almost yellow, with plain light. However, in cross-polarized light the tone of the matrix is quite dark, even at $800{ }^{\circ} \mathrm{C}$, which indicates that a significant degree of vitrification has already been reached at this temperature. Carbonates are completely decomposed and muscovite do not reach the same levels of birefringence as in the bricks made without additives or with diatomite sludge (Fig. 3e). At $950{ }^{\circ} \mathrm{C}$ and 1100 ${ }^{\circ} \mathrm{C}$ bricks are still not very birefringent and only quartz crystals and small whitish sheets of pseudomorphs of phyllosilicates can be identified. Most of the pores are round in shape (Fig. 3f).

\subsection{FESEM and VPSEM analyses of the microtexture of the bricks and chemical distribution of mineral phases}

FESEM observation shows that carbonates are totally fractured at $800{ }^{\circ} \mathrm{C}$, while with higher magnification the presence of a microporosity can be observed, indicating the incipient decomposition of these minerals and the release of $\mathrm{CO}_{2}$. Phyllosilicates maintain their laminar habit, although the sheets tend to separate along the basal planes (Fig. 4a). At $950{ }^{\circ} \mathrm{C}$ phyllosilicates begin to lose this habit due to the partial melting of crystals and develop a secondary porosity in the molten areas due to the release of gases (Fig. 4b) (Cairo et al., 2001). Some phyllosilicates adjacent to the melted crystals seem to be well preserved from the melting. The angular shape of the quartz grains can also be observed (Fig. 4b). At this temperature, the reaction rims between silicates and carbonates can be seen. These give rise to the formation of gehlenite and even wollastonite. In the case of gehlenite, the EDX analysis has revealed the presence of $\mathrm{Mg}$, albeit in much smaller quantities than $\mathrm{Si}, \mathrm{Al}$ and $\mathrm{Ca}$. Pure gehlenite is not therefore being formed but an intermediate phase of the åkermanite-gehlenite series (end-members of the melilite group), which is quite a lot richer in aluminium (gehlenite) than in magnesium (åkermanite). Åkermanite-gehlenite solid solution has been detected in ash residues (poor in silica and aluminium but very rich in calcium) treated by thermal plasma vitrification at temperatures similar to the firing temperatures of the bricks studied in this research (Cheng et al., 2002). However, in studies of brick mineralogy one is more likely to find references solely to gehlenite (Marrocchino et al., 2010; López Arce et al., 2003; Scatigno et al., 2018), probably because this was the name used for the entire solid solution (Dondi et al., 1999). It is important to bear in mind that X-ray diffraction technique is unable to distinguish the end members of the melilite group clearly (Dondi et al., 1999). Conversely, the presence of åkermanite in common bricks has been identified much less often (Çelik et al., 2019). In the light of FESEM observations and EDX microanalyses, we therefore hypothesize that the gehlenite identified by PXRD in our ceramic material is a more generic melilite, even if it is rich in Al.

At $1100{ }^{\circ} \mathrm{C}$ phyllosilicates have lost their laminar habit almost entirely, the reaction between quartz and carbonates is more widespread and the matrix is vitrified, developing spherical or oval-shaped pores ("cellular structure" according to Tite and Maniatis, 1975). Anhydrite crystals are cracked and contracted compared to the matrix, as was observed under the optical microscope. The reaction between anhydrite and silicate was rarely observed and the formation of new mineral phases such as wollastonite (Fig. 4c) was due above all to the sum of two factors: firstly, the contraction of calcium sulphate during the firing of bricks insulated it from the silicate-rich matrix; secondly, the high temperature at which anhydrite normally decomposes may have made the formation of new phases more difficult. Indeed, the decomposition of anhydrite should begin at temperatures of over $1180{ }^{\circ} \mathrm{C}$, in other words higher than the maximum firing temperature for our bricks. However, Yan et al. (2015) demonstrated that in the presence of other mineral phases such as quartz, anhydrite may start decomposing earlier, at $1000^{\circ} \mathrm{C}$. In this case, silica is consumed to form wollastonite and grains edges are increasingly smooth (Fig. 3c) according to the following reaction:

anhydrite quartz wollastonite

$\mathrm{CaSO} 4+\mathrm{SiO}_{2} \rightarrow \mathrm{CaSiO}_{3}+\mathrm{SO}_{3}$

The same authors also suggest the formation of larnite $\left(\mathrm{Ca}_{2} \mathrm{SiO}_{4}\right)$ together with wollastonite, although in our study larnite was not detected by $\mathrm{x}$-ray diffraction nor was it suggested by EDX microanalysis. According to PXRD analyses, the reaction (8) must have taken place more frequently in bricks made with halite. Indeed, this technique highlighted that anhydrite had only disappeared in the $\mathrm{JH}$ bricks fired at $1100{ }^{\circ} \mathrm{C}$ (Table 2), 
supposedly being consumed in the reaction with the silicates. In bricks made with calcined diatomite sludge diatom fragments were identified (white arrow, Fig. 4d). The reactions between the mineral phases were the same as those observed in bricks made without additives. At $1100{ }^{\circ} \mathrm{C}$, the presence of gehlenite and the elongated habit of wollastonite crystals can be clearly distinguished (Fig. 4e). In bricks that contain halite, the newly-formed phases appeared earlier than in the other two groups of bricks. At $800{ }^{\circ} \mathrm{C}$ reactions between mineral phases were quite widespread, grain edges were smooth and EDX analyses identified the formation of gehlenite, anorthite and wollastonite, as well as the constant presence of chlorine in spectra. (Fig. 4f). At higher temperatures, diopside was also identified. Unique to this group of bricks were the development of totally melted, circular or oval-shaped areas with pores of about $10 \mu \mathrm{m}$ in length (Fig. $4 \mathrm{~g}$ ). These areas may correspond to the yellow stains on the fired bricks that were observed at a macroscopic level. Some framboidal iron crystals, probably hematite were also identified (white arrow, Fig. 4h). Framboidal morphology suggests that they may be pyrite crystals that lost sulphur due to the decomposition of these sulphides at $588{ }^{\circ} \mathrm{C}$ and, in an oxidising atmosphere, they transformed into $\mathrm{Fe}_{2} \mathrm{O}_{3}$ (Brownell, 1976). Accessory minerals that could not be identified by other means, such as rutile, celestine, apatite, zircon and fluorite were also recognized.

FESEM observations enabled us to identify some of the newly-formed phases which were not detected by PXRD due to their low concentrations. All of these phases hadmorphologies linked to their rapid growth in supersaturation environments. One example is mullite, whose presence was not only detected in bricks made with halite and not only in those fired at $1100{ }^{\circ} \mathrm{C}$. Indeed, skeletal habits of this aluminium silicate could be observed by $950^{\circ} \mathrm{C}$ in bricks made with no additives (Fig. 5a). The morphology of these crystals is very similar to that observed by Rodríguez Navarro et al. (2003) and it is probable that they were formed from illite/muscovite according to reaction (7). The image does not show the presence of phyllosilicates due to the fact that they probably converted into a metastable molten mass with a composition similar to that of feldspar (Rodríguez Navarro et al., 2003). EDX analysis revealed a low Mg and Fe content in the composition of mullite. Schneider et al. (2015) demonstrated that a wide variety of cations may be incorporated into the structure of these silicates.

Cordierite $\left(\mathrm{Mg}_{2} \mathrm{Al}_{4} \mathrm{Si}_{5} \mathrm{O}_{18}\right)$ crystals were identified at $950{ }^{\circ} \mathrm{C}$, some with dendritic growth (Fig. 5b). The EDX analysis has revealed that this silicate is somewhat lacking in $\mathrm{Si}$ and contains some $\mathrm{Fe}$. It would therefore appear to be an intermediate phase of the cordierite-sekaninaite series. According to Sedmale et al. (2006), cordierite crystallizes at temperatures of over $1200{ }^{\circ} \mathrm{C}$ and is produced by the decomposition of illite and dolomite. Kurama and Kurama (2008) identified cordierite at $1150{ }^{\circ} \mathrm{C}$ after the reaction of kaolinite and talc with aluminium. More recently, Coletti et al. (2018) observed the formation of cordierite at $900{ }^{\circ} \mathrm{C}$ due to the decomposition of chlorite and/or biotite and its reaction with illite and feldspars. Bearing in mind the mineralogical composition of the clayey earth from Jun, it seems likely that illite and chlorite have reacted with quartz to form cordierite and K-feldspar as follows:

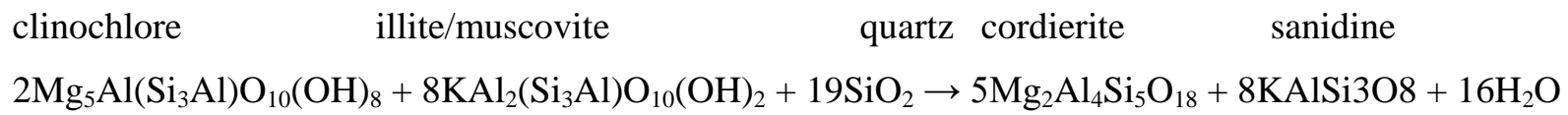

Another phase identified in bricks fired at $1100{ }^{\circ} \mathrm{C}$ was hercynite $\left(\mathrm{FeAl}_{2} \mathrm{O}_{4}\right)$, a spinel that is normally formed by the metamorphism of iron-rich clay sediments (Fig. 5c). According to Jordan et al. (1999) and Maritan et al. (2006), the formation of this oxide was probably due to the decomposition of illite/muscovite, although in this case the presence of iron, which was identified in the raw material by XRF (Table 2), is also required. The iron necessary for the formation of hercynite (as nanoparticles of iron oxide according to Maniatis et al., 1980 and Nodari et al., 2007) could also be provided by the thermal decomposition of Fe-rich clay minerals such as chlorite (Fig. 1a). When clay minerals decompose, part of the iron is oxidised to form wüstite (FeO) (Saiah et al., 2010), a very reactive component in solid-state reactions (Maniatis et al., 1983). It is also very likely that the organic material identified in the clayey earth (Fig. 2) has established partially reduction conditions in which part of the $\mathrm{Fe}_{2} \mathrm{O}_{3}$ particles (hematite) were converted into $\mathrm{FeO}$. It has also been demonstrated that $\mathrm{Fe}_{2} \mathrm{O}_{3} \rightarrow \mathrm{FeO}$ conversion happens more quickly as the temperature increases (Piotrowski et al., 2007). It is possible therefore, that hercynite may have been formed as a result of the following reaction:

illite/muscovite wüstite hercynite sanidine

$3 \mathrm{KAl}_{2}\left(\mathrm{Si}_{3} \mathrm{Al}\right) \mathrm{O}_{10}(\mathrm{OH})_{2}+\mathrm{FeO} \rightarrow \mathrm{FeAl}_{2} \mathrm{O}_{4}+\mathrm{KAlSi}_{3} \mathrm{O}_{8}+\mathrm{H}_{2} \mathrm{O}$ 
In Figure 5c it is interesting to note the different size of hercynite crystals at the edge (a lot of small crystals) and in the centre (a few large ones). The smaller crystals probably formed thanks to the presence of numerous nucleation points and abundance of ions. In the centre there were fewer nucleation points and crystals were formed by ions that were gradually incorporated and made the crystals bigger. It is interesting to note how bigger crystals seem to show the "imperfect oriented attachment" described by Penn and Banfield (1998) in which nanocrystalline particles grow according to spontaneous self-organization with slight misorientation in the contact surface of grains, so that they share a common crystallographic orientation.

Finally, at $1100{ }^{\circ} \mathrm{C}$ ilmenite $\left(\mathrm{FeTiO}_{3}\right)$ was detected (Fig. 5d). The formation of this oxide was described in bricks fired at $950{ }^{\circ} \mathrm{C}$ by a reaction between $\mathrm{TiO}_{2}$ and $\mathrm{Fe}_{2} \mathrm{O}_{3}$ in the presence of $\mathrm{H}_{2} \mathrm{O}$ (Temuujin et al., 2012). The intercalation of hematite between the sheets of phyllosilicates was also observed, a phenomenon visible above all in bricks fired at the highest temperature.

$\mathrm{X}$-ray maps performed on bricks fired at $1100{ }^{\circ} \mathrm{C}$ enabled us to make important observations. In the presence of anhydrite, $\mathrm{Mg}$ and to a lesser extent $\mathrm{Na}$ become part of well-developed rims of wollastonite around quartz (Fig. 6). Wollastonite does not therefore correspond to a stoichiometric phase as might initially be expected. Mg-rich wollastonite has been found in interplanetary dust particles which suffer a kind of pyrometamophism with rapidly heated and quenched products (Rietmeijer, 1999), and also in ultra-hightemperature paralavas $\left(\mathrm{T}>1150{ }^{\circ} \mathrm{C}\right)$ in which a pyrometamorphic event occurred by combustion (Seryotkin, et al 2012). The incorporation of $\mathrm{Mg}$, produced by the decomposition of the dolomite, provides stability to the pure wollastonite, which at atmospheric pressure is only stable up to temperatures of less than $1125 \pm 10$ ${ }^{\circ} \mathrm{C}$ (Osborn and Schairer, 1941).

These maps also show how plagioclase (Ans, Fig. 6) is transformed into gehlenite, incorporating some $\mathrm{Mg}$ and, to a lesser extent, Na. This confirms and completes the previous FESEM observations. It is important to make clear that $\mathrm{Fe}$ is not incorporated in appreciable amounts, which would suggest that Fe was not available (fixed as hematite and hercynite) at the time gehlenite was formed.

\section{Conclusions}

A mineralogical and textural study of solid bricks made with and without additives and fired at between 800 ${ }^{\circ} \mathrm{C}$ and $1100^{\circ} \mathrm{C}$ was conducted. This study enabled us to chart the process of formation of metastable mineral phases which developed at high temperature and atmospheric pressure and which replicate, albeit at small scale, pyrometamorphic processes (Grapes, 2006). The development of these phases was caused above all by the reaction between carbonates (calcite and dolomite) and silicates (quartz, phyllosilicates and feldspars). Xray diffraction identified phases such as gehlenite, diopside, wollastonite, anorthite and mullite, whose appearance and abundance varied depending on the firing temperature, the change in the polymorphs of Kfeldspar, and the presence of molysite only in bricks made with added halite. The addition of halite accelerated the formation of new mineral phases because it acts as a melting agent. For its part, the addition of calcined diatomite sludge did not cause any significant change in the mineralogy with the exception of the appearance of cristobalite, which was already present in the additive. X-ray diffraction also estimated the increase in the amorphous phase as firing temperature increased, a phenomenon linked to the gradual vitrification of bricks, as confirmed by polarized optical microscopy (reduction in the birefringence of samples) and scanning electron microscopy (presence of totally or partially melted areas) observations. The vitrification affected above all the phyllosilicates in which rounded pores developed. The water released by these minerals due to dehydroxylation may have facilitated the formation of melt (Rodriguez Navarro et al., 2003). Totally melted, oval-shaped areas were observed in bricks made with added halite, which may correspond to the yellow stains on this group of samples visible with the naked eye. The diatom fragments were easily recognizable under the scanning electron microscope in bricks made with added calcined diatomite sludge. Scanning electron microscope enabled to identify other phases, which had not been detected by X-ray diffraction due to their very low content. Examples include accessory minerals such as rutile, celestine, apatite, zircon, ilmenite and fluorite. It was also interesting to observe how the rapid formation of newly-formed crystals (the firing-cooling process took a total of 24 hours) influenced both the crystalline morphologies (skeletal or dendritic) and the presence of chemical elements not normally observed in the standard composition of the mineral phases. Wollastonite developed as a reaction rim between carbonates and quartz, rounding the edges of $\mathrm{SiO}_{2}$. This calcium silicate was also formed by reaction with 
anhydrite, although less frequently. At times, needle-shaped morphology of wollastonite and the presence of low $\mathrm{Mg}$ concentrations in its chemical composition were observed. $\mathrm{Mg}$ (together with small amounts of $\mathrm{Na}$ ) was also detected in gehlenite composition. This means that the newly formed phase identified was probably a melilite of the åkermanite-gehlenite series. Mullite has grown with a skeletal habit and included some Fe and $\mathrm{Mg}$ in its structure. Cordierite showed some crystals with dendritic growth, as well as a lack of Si and some Fe content, which indicates that this mineral phase was not a pure cordierite but rather an intermediate phase of the cordierite-sekaninaite series.

This study has provided new data about the reactions between mineral phases and the changes in the texture of bricks made with a clayey earth that was rich in carbonates and contained sulphates. It also sheds light on the ways in which the additives (halite and calcined diatomite sludge) influence these reactions.

\section{Acknowledgments}

This study was funded by Junta de Andalucía Research Group RNM179 and by the Research Project MAT2016-75889-R. We thank Cerámica Castillo Siles for providing the raw material used to prepare and fire the bricks and Cervezas Alhambra S.L. (Granada) for providing the calcined diatomite sludge with yeast. We are grateful to Nigel Walkington for his assistance in translating the original text.

\section{References}

Abbas, S., Saleem, M.A., Kazmi, S.M.S., Munir, M.J., 2017. Production of sustainable clay bricks using waste fly ash: mechanical and durability properties. J. Build. Eng. 14, 7-14.

Al Fakih, A., Mohammed, B.S., Shahir Liew, M., Nikbakht, E., 2019. Incorporation of waste materials in the manufacture of masonry bricks: an update review. J. Build. Eng. 21, 37-54.

Bilgin, N., Yeprem, H.A., Arslan, S., Bilgin, A., Günay, E., Marsoglu, M., 2012. Use of waste marble powder in brick industry. Constr. Build. Mater. 29, 449-457.

Bories, C., Aouba, L., Vedrenne, E., Vilarem, G., 2015. Fired clay bricks using agricultural biomass wastes: study and characterization. Constr. Build. Mater. 91, 158-163.

Bories, C., Borredon, M.E., Vedrenne, E., Vilarem, G., 2014. Development of eco-friendly porous fired clay bricks using pore-forming agents: a review. J. Environ. Manage. 143, 186-196.

Brownell, W.E., 1976. Structural clay products. Applied Mineralogy 9, Springer Verlag, Vienna, 231 pp.

Cairo, A., Messiga, B., Riccardi, M.P., 2001. Technological features of "Cotto Variegato": a petrological approach. J. Cult. Herit. 2, 133-142.

Cerdeño del Castillo, J., Díaz Rubio, R., Obis Sánchez, J., Pérez Lorenzo, A., Velasco Vélez, J., 2010. Manual de patologías de las piezas cerámicas para la construcción. AITEMÍN, Toledo (Spain).

Cultrone, G., Rodriguez Navarro, C., Sebastián, E., Cazalla, O., de la Torre, M.J., 2001. Carbonate and silicate phase reactions during ceramic firing. Eur. J. Mineral. 13, 621-634.

Cultrone, G., Sebastian, E., de la Torre, M.J., 2005. Mineralogical and physical behaviour of solid bricks with additives. Constr. Build. Mater. 19, 39-48.

Capel, J., Huertas, F., Linares, J., 1985. High temperature reactions and use of Bronze Age pottery from La Mancha, Central Spain. Mineralogica Petrographica Acta, 29A, 563-575.

Çelik, A., Kadir, S., Kapur, S., Zorlu, K., Akça, E., Akşit, Í., Cebeci, Z., 2019. The effect of high temperature minerals and microstructure on the compressive strength of bricks. Appl. Clay Sci. 169, 91-101.

Cheng, T.W., Chu, J.P., Tzeng, C.C., Chen, Y.S., 2002. Treatment and recycling of incinerated ash using thermal plasma technology. Waste Manage. 22, 485-490.

Coletti, C., Maritan, L., Cultrone, G., Dalconi, M.C., Hein, A., Molina, E., Mazzoli, C., 2018. Recycling trachyte waste from the quarry to the brick industry: effects on physical and mechanical properties, and durability of new bricks. Constr. Build. Mater. 166, 792-807.

Demir, I., 2008. Effect of organic residues addition on the technological properties of clay bricks. Waste Manage. 28, 622-627.

Demir, I., Baspinar, M.S., Orhan, M., 2005. Utilization of kraft pulp production residues in clay brick production. Build. Environ. 40, 1533-1537. 
Dondi, M., Ercolani, G., Fabbri, B., Marsigli, M., 1999. Chemical composition of melilite formed during the firing of carbonate-rich and iron-containing ceramic bodies. J. Am. Ceram. Soc. 82, 465-468.

Ediz, N., Bentli, I., Tatar, I., 2010. Improvement in filtration characteristics of diatomite by calcination. Int. J. Miner. Process. 94, 129-134.

Fernandes, F.M., Lourenço, P.B., Castro, F., 2010. Ancient clay bricks: manufacture and properties. In: Materials, Technologies and Practice in Historic Heritage (M. Bostenaru Dan, R. Přikryl, A. Török, eds.), Springer, Dordrecht (Netherlands), 29-48.

Fernández Pereira, C., de la Casa, J.A., Gómez Barea, A., Arroyo, F., Leiva, C., Luna, Y., 2011. Application of biomass gasification fly ash for brick manufacturing. Fuel, 90, 220-232.

Galán Arboledas, R.J., Cotes Palomino, M.T., Bueno, S., Martínez García, C., 2017. Evaluation of spent diatomite incorporation in clay-based materials for lightweight bricks processing. Constr. Build. Mater. $144,327-337$.

Galán, E., González, I., Mayoral, E., Miras, A., 1993. Properties and applications of diatomitic materials from SW Spain. Appl. Clay Sci. 8, 1-18.

Gómez, J., Gil, M.L.A., de la Rosa Fox, N., Alguacil, M., 2015. Formation of siliceous sediments in brandy after diatomite filtration. Food Chem. 170, 84-89.

Grapes, R., 2005. Pyrometamorphism. Springer, Heidelberg.

Guggenheim, S., Chang, Y.H., Koster Van Groos, A.F., 1987. Muscovite dihydroxylation: high temperature studies. Am. Mineral. 72, 537-550.

Guo, F., Wu, F., Mu, Y., Hu, Y., Zhao, X., Meng, W., Giesy, J.P., Lin, Y., 2016. Characterization of organic matter of plants from lakes by thermal analysis in a N2 atmosphere. Sci. Rep. 6, 22877.

Hadjar, H., Hamdi, B., Jaber, M., Brendlé, J., Kessaïssia, Z., Balard, H., Donnet, J.B., 2008. Elaboration and characterization of new mesoporous materials from diatomite and charcoal. Micropor. Mesopor. Mat. 107, 2019-226.

Hojamberdiev, M., Eminov, A., Xu, Y., 2011. Utilization of muscovite granite waste in the manufacture of ceramic tiles. Ceram. Int. 37, 871-876.

Jordan, M.M., Boix, A., Sanfeliu, T., de la Fuente, C., 1999. Firing transformations of cretaceous clays used in the manufacturing of ceramic tiles. Appl. Clay Sci. 14, 225-234.

Kazmi, S.M.S., Munir, M.J., Wu, Y.F., Hanif, A., Patnaikuni, I. 2018. Thermal performance evaluation of eco-friendly bricks incorporating waste glass sludge. J. Clean. Prod. 172, 1867-1880.

Koseoglu, K., Polat, M., Polat, H., 2010. Encapsulating fly ash and acidic process waste water in brick structure. J. Hazard. Mater. 176, 957-964.

Kurama, S., Kurama, H., 2008. The reaction kinetics of rice husk based cordierite ceramics. Ceram. Int. 34, 269-272.

La Rubia García, M.D., Yebra Rodríguez, A., Eliche Quesada, D., Corpas Iglesias, F.A., López Galindo, A., 2012. Assessment of olive mil solid residue (pomace) as an additive in lightweight brick production. Constr. Build. Mater. 36, 495-500.

Laird, R.T., Worcerster, M., 1956. The inhibiting of lime blowing. Trans. Brit. Ceram. Soc. 55, 545-563.

Leiva, C., Arenas, C., Alonso Fariñas, B., Vilches, L.F., Peceño, B., Rodríguez Galán, M., Baena, F., 2016. Characteristics of fired bricks with co-combustion fly ashes. J. Build. Eng. 5, 114-118.

Lingling, X., Wei, G., Tao, W., Nanru, Y., 2005. Study on fired bricks with replacing clay by fly ash in high volume ratio. Constr. Build. Mater. 19, 243-247.

López Arce, P., Garcia Guinea, J., Gracia, M., Obis, J., 2003. Bricks in historical buildings of Toledo City: characterisation and restoration. Mater. Charact. 50, 59-68.

Lupiani Moreno, E., Soria Mingorance, J., 1988. Memoria de la Hoja n. 1009 (Granada). Mapa Geológico de España 1:50000. Instituto Geológico Minero de España, Servicio de Publicaciones, Ministerio de Industria y Energía, $73 \mathrm{pp}$.

Man, J., Gao, W., Yan, S., Liu, G., Hao, H., 2017. Preparation of porous brick from diatomite and sugar filter mud at lower temperature. Constr. Build. Mater. 156, 1035-1042.

Maniatis, Y., Simopoulos, A., Kostikas, A., 1980. Moessbauer study of the effect of calcium content on iron oxide transformation in fired clays. J. Am. Ceram. Soc. 64, 263-269.

Maniatis, Y., Simopoulos, A., Kostikas, A., Predikatsis, V., 1983. Effect of reducing atmosphere on minerals and iron oxides developed in fired clays: the role of Ca. J. Am. Ceram. Soc. 66, 773-781.

Maniatis, Y., Tite, M.S., 1981. Technological examination of Neolithic-Bronze Age pottery form central and southeast Europe and from the Near East. J. Archaeol. Sci. 8, 59-76.

Maritan, L., Nodari, L., Mazzoli, C., Milano, A., Russo, U., 2006. Influence of firing conditions on ceramic products: experimental study on clay rich in organic matter. Appl. Clay Sci. 31, 1-15. 
Marrocchino, E., Rapti Caputo, D., Vaccaro, C., 2010. Chemical-mineralogical characterisation as useful tool in the assessment of the decay of Mesola Castle (Ferrara, Italy). Constr. Build. Mater. 24, 26722683.

Martin, J.D., 2016. XPowder, XPowder12, XPowderXTM. A software package for powder X-ray diffraction analysis, Lgl. Dp. GR-780-2016.

Martínez, C., Cotes, T., Corpas, F.A., 2012. Recovering wastes from the paper industry: development of ceramic materials. Fuel Process. Tech. 103, 117-124.

Matsunaga, C., Fukushima, M., Hyuga, H., Yoshizawa, Y., 2017. Fabrication of porous silica ceramics by gelation-freezing of diatomite slurry. J. Eur. Ceram. Soc. 37, 5259-5264.

Monteiro, S.N., Fontes Vieira, C.M., 2014. On the production of fired clay bricks from waste materials: a critical update. Constr. Build. Mater. 68, 599-610.

Muñoz Velasco, P., Morales Ortiz, M.P., Mendívil Giro, M.A., Juárez Castelló, M.C., Muñoz Velasco, L., 2014. Development of better insulation bricks by adding mushroom compost wastes. Energ. Buildings, $80,17-22$.

Nodari, L., Marcuz, E., Maritan, L., Mazzoli, C., Russo, U., 2007. Hematite nucleation and growth in the firing of carbonate-rich clay for pottery production. J. Eur. Ceram. Soc. 27, 4665-4673.

Parsons, I., 2014. Friendly brick. Elements, 10, 237-238.

Penn, R.L., Banfield, J.F., 1998. Imperfect oriented attachment: dislocation generation in defect-free nanocrystals. Science, 281, 969-971.

Pérez Villarejo, L., Eliche Quesada, D., Iglesias Godino, F.J., Martínez García, C., Corpas Iglesias, F.A., 2012. Recycling of ash from biomass incinerator in clay matrix to produce ceramic bricks. J. Environ. Manage. 95, S349-S354.

Osborn, F.F., Schairer, J.F., 1941. The ternary system pseudowollastonite-akermanite-gehlenite. Am. J. Sci. 239, 715-763.

Phonphuak, N., Thiansem, S., 2012. Using charcoal to increase the properties and durability of fired test briquettes. Constr. Build. Mater. 29, 612-618.

Piotrovski, K., Mondal, K., Wiltowski, T., Dydo, P., Rizeg, G., 2007. Topochemical approach of kinetics of the reduction of hematite to wüstite. Chem. Eng. J. 131, 73-82.

Rietmeijer, F.J.M., 1999. Metastable non-stoichiometric diopside and Mg-wollastonite: An occurrence in an interplanetary dust particle. Am. Mineral. 84, 1883-1894.

Rodriguez Navarro, C., Cultrone, G., Sánchez Navas, A., Sebastián, E., 2003. TEM study of mullite growth after muscovite breakdown. Am. Mineral. 88, 713-724.

Rodriguez Navarro, C., Ruiz Agudo, E., Luque, A., Rodriguez Navarro, A.B., Ortega Huertas, M., 2009. Thermal decomposition of calcite: mechanisms of formation and textural evolution of $\mathrm{CaO}$ nanocrystals. Am. Mineral. 94, 578-593.

Rye, O.S., 1976. Keeping your temper under control: Materials and manufacture of Papuan pottery. Archaeol. Phys. Anthropol. Oceania, 11, 106-137.

Saiah, R., Perrin, B., Rigal, L., 2010. Improvement of thermal properties of fired clays by introduction of vegetable matter. J. Build. Phys. 34, 124-142.

Scatigno, C., Prieto Taboada, N., Preite Martinez, M., Conte, A.M., Madariaga, J.M., 2018. A non-invasive spectroscopic study to evaluate both technological features and conservation state of two types of ancient Roman coloured bricks. Spectrochim. Acta A. 204, 55-63.

Seryotkin, Y.V., Sokol, E.V., Kokh, S.N., 2012. Natural pseudowollastonite: Crystal structure, associated minerals, and geological context. Lithos, 134-135, 75-90.

Shakir, A.A., Mohammed, A.A., 2013. Manufacturing of bricks in the past, in the present and in the future: a state of the art review. Int. J. Adv. Appl. Sci. 2, 145-156.

Schairer, J.F., Osborn, E.F., 1943. The system CaO-MgO-FeO-SiO2: I. Preliminary data on the join CaSiO3$\mathrm{MgO}-\mathrm{FeO}$. Eos, 24, 251-252.

Shnaider, H., Fischer, R.X., Schreurer, J., 2015. Mullite: crystal structure and related properties. J. Am. Ceram. Soc. 98, 2948-2967.

Stimmell, C., Heimann, R.B., Hancock, R.G.V., 1987. Indian pottery from Mississippi valley: coping with bar raw materials. In: Archaeological Ceramics, Smithsonian Institution Press, 219-228.

Sutcu, M., Alptekin, H., Erdogmus, E., Er, Y., Gencel, O., 2015. Characteristics of fired clay bricks with waste marble powder addition as building materials. Constr. Build. Mater. 82, 1-8.

Sutcu, M., del Coz Díaz, J.J., Álvarez Rabanal, F.P., Gencel, O., Akkurt, S., 2014. Thermal performance optimization of hollow clay bricks made up of paper waste. Energ. Buildings, 75, 96-108. 
Temuujin, J., Jadambaa, T., Hayashi, S., 2012. Preparation of coloured facing brick from low melting clay under a water vapour atmosphere. In Brick and Mortar Research, pp. 215-230. Nova Science Publishers, Inc.

Tite, M.S., Maniatis, Y., 1975. Examination of ancient pottery using the scanning electron microscope. Nature, 257, 122-123.

Whiteney, D.L., Evans, B.W., 2010. Abbreviations for names of rock-forming minerals. Am. Mineral. 95, $185-187$.

Yan, A., Wang, Z., Liu, H., Tu, Y., Yang, W., Zeng, H., Qiu, J., 2015. Decomposition and solid reactions of calcium sulfate doped with $\mathrm{SiO} 2, \mathrm{Fe} 2 \mathrm{O} 3$ and Al2O3. J. Anal. Appl. Pyrol. 113, 491-498.

Zhang, H., Qi, J., 2012. Reuse of air pollution control ash. Environmental Engineering Science, 29, 902-906.

Zhang, L., 2013. Production of bricks from waste materials. A review. Constr. Build. Mater. 47, 643-655.

Zhang, X., Liu, X., Meng, G., 2005. Sintering kinetics of porous ceramics from natural diatomite. J. Am. Ceram. Soc. 88, 1826-1830.

Zheng, R., Ren, Z., Gao, H., Zhang, A., Bian, Z., 2018. Effects on calcination on silica phase transition in diatomite. J. Alloy. Compd. 757, 364-371. 
Table 1. Acronyms of the samples based on their composition and firing temperature.

\begin{tabular}{clccc}
\hline & Composition & \multicolumn{3}{c}{ Firing temperature } \\
& & $800^{\circ} \mathrm{C}$ & $950{ }^{\circ} \mathrm{C}$ & $1100{ }^{\circ} \mathrm{C}$ \\
\hline \multirow{2}{*}{$\begin{array}{c}\text { Clayey earth } \\
\text { from Jun }\end{array}$} & no additive & $\mathrm{J} 800$ & $\mathrm{~J} 950$ & $\mathrm{~J} 1100$ \\
& calcined diatomite sludge with yeast & $\mathrm{JD} 800$ & $\mathrm{JD} 950$ & $\mathrm{JD} 1100$ \\
& halite & $\mathrm{JH} 800$ & $\mathrm{JH} 950$ & $\mathrm{JH} 1100$ \\
\hline
\end{tabular}

Table 2. Chemical analysis of major oxides (in wt.\%) in the clay raw material. LOI stands for loss on ignition.

\begin{tabular}{llllllllllll}
\hline & $\mathrm{SiO}_{2}$ & $\mathrm{Al}_{2} \mathrm{O}_{3}$ & $\mathrm{Fe}_{2} \mathrm{O}_{3}$ & $\mathrm{MnO}$ & $\mathrm{MgO}$ & $\mathrm{CaO}$ & $\mathrm{Na}_{2} \mathrm{O}$ & $\mathrm{K}_{2} \mathrm{O}$ & $\mathrm{TiO}_{2}$ & $\mathrm{P}_{2} \mathrm{O}_{5}$ & LOI \\
\hline $\mathrm{J}$ & 48.87 & 16.54 & 5.75 & 0.07 & 2.93 & 9.31 & 0.81 & 2.88 & 0.72 & 0.14 & 11.78 \\
\hline
\end{tabular}

Table 3. Mineralogical composition of fired bricks. Legend: $\mathrm{Qz}=$ quartz; Ilt = illite/muscovite; $\mathrm{Pg}$ = paragonite Cal = calcite Anh $;$ anhydrite Hem = hematite Or $=$ orthoclase $; \mathrm{Sa}=$ sanidine $;$ Ans = andesine; $\mathrm{An}=$ anorthite $; \mathrm{Gh}=$ gehlenite; $\mathrm{Wo}=$ wollastonite; $\mathrm{Di}=$ diopside $; \mathrm{Mul}=$ mullite $; \mathrm{Crs}=$ cristobalite; Mo = molysite; $\mathrm{a} / \mathrm{c}=$ amorphous/crystals ratio. Mineral abbreviations after Whitney and Evans (2010).

\begin{tabular}{lrrrrrrrrr}
\hline & J800 & J950 & J1100 & JD800 & JD950 & JD1100 & JH800 & JH950 & JH1100 \\
\hline Qz & 35.44 & 29.06 & 29.62 & 44.55 & 33.81 & 21.87 & 46.04 & 29.16 & 22.02 \\
Ilt & 8.79 & 6.59 & & 9.18 & 6.95 & & 7.33 & 2.99 & \\
Pg & 5.63 & & & 4.83 & & & 5.21 & & \\
Cal & 2.07 & & & 2.33 & & & & & \\
Anh & 9.14 & 10.91 & 9.55 & 10.62 & 11.83 & 8.21 & 11.31 & 8.26 & \\
Hem & & 1.80 & 1.69 & 0.99 & 1.49 & 1.33 & 1.00 & 0.86 & 1.21 \\
Or & 9.86 & & & 16.04 & & & 15.62 & & \\
Sa & & 4.42 & 3.15 & & 5.42 & 5.06 & & 3.92 & 5.53 \\
Ans & 29.06 & & & 10.67 & & & 10.07 & & \\
An & & 41.10 & 41.08 & & 33.49 & 47.59 & & 39.23 & 50.75 \\
Gh & & 6.13 & 3.86 & & 6.09 & 3.82 & & 1.85 & 1.49 \\
Wo & & & 5.06 & & & 3.84 & & 4.01 & 4.75 \\
Di & & & 6.00 & & & 6.35 & & 6.31 & 9.91 \\
Mul & & & & & & & & & 2.10 \\
Crs & & & & 0.80 & 0.91 & 1.92 & & & \\
Mo & & & & & & & 3.43 & 3.40 & 2.23 \\
a/c & 0.063 & 0.071 & 0.083 & 0.061 & 0.067 & 0.122 & 0.053 & 0.077 & 0.108 \\
\hline
\end{tabular}




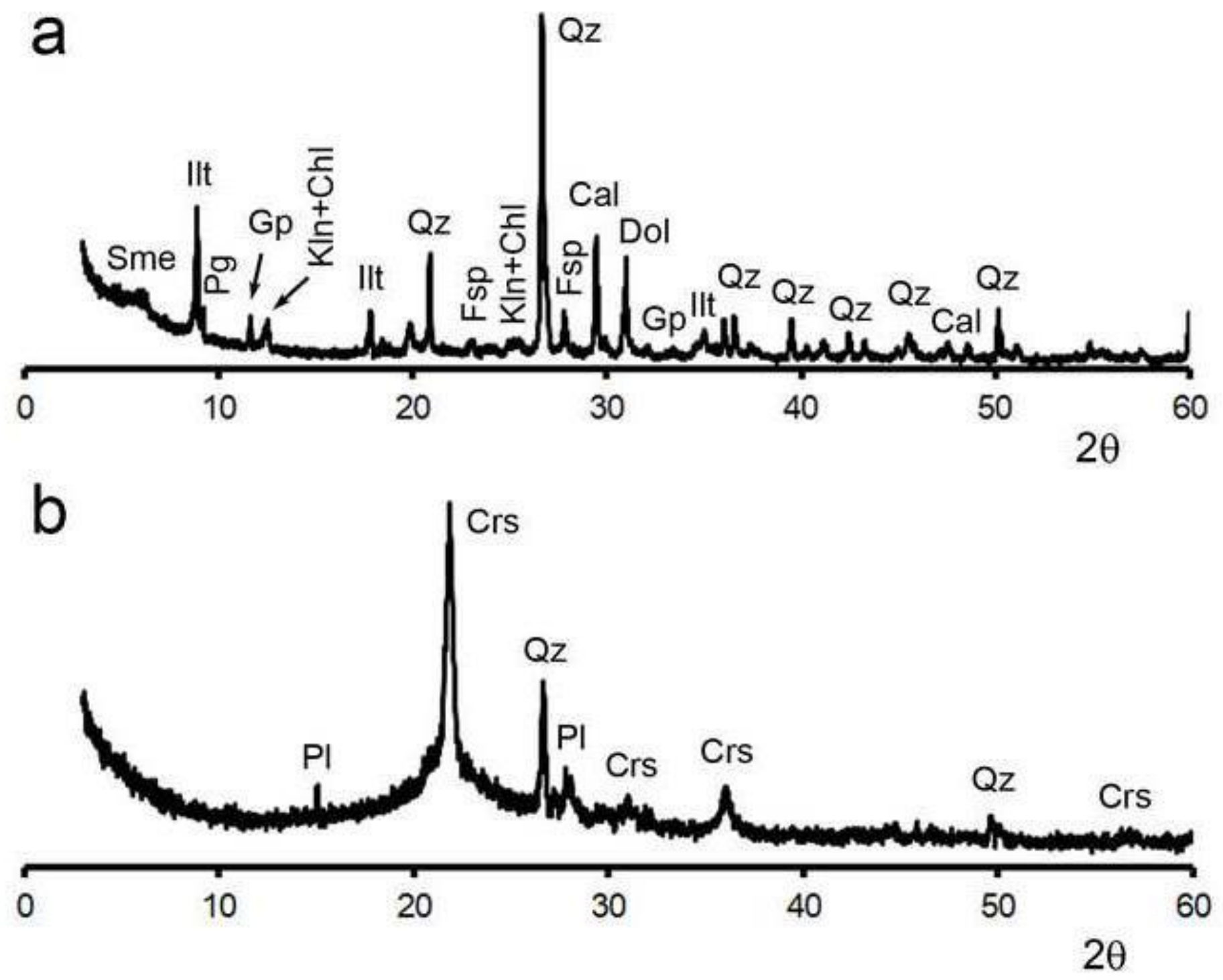

Figure 1. X-ray diffraction patterns of raw material from Jun (a) and of calcined diatomite sludge with yeast (b). Legend: Sme = smectites; Ilt = illite/muscovite; Pg = paragonite; Gp = gypsum; Kln+Chl = kaolinite + chlorite; Qz = quartz; Fsp = feldspars s.l.; $\mathrm{Cal}=$ calcite $; \mathrm{Dol}=$ dolomite $\mathrm{Pl}=$ plagioclase $; \mathrm{Crs}=$ cristobalite. Minerals abbreviations after Whitney and Evans (2010). 


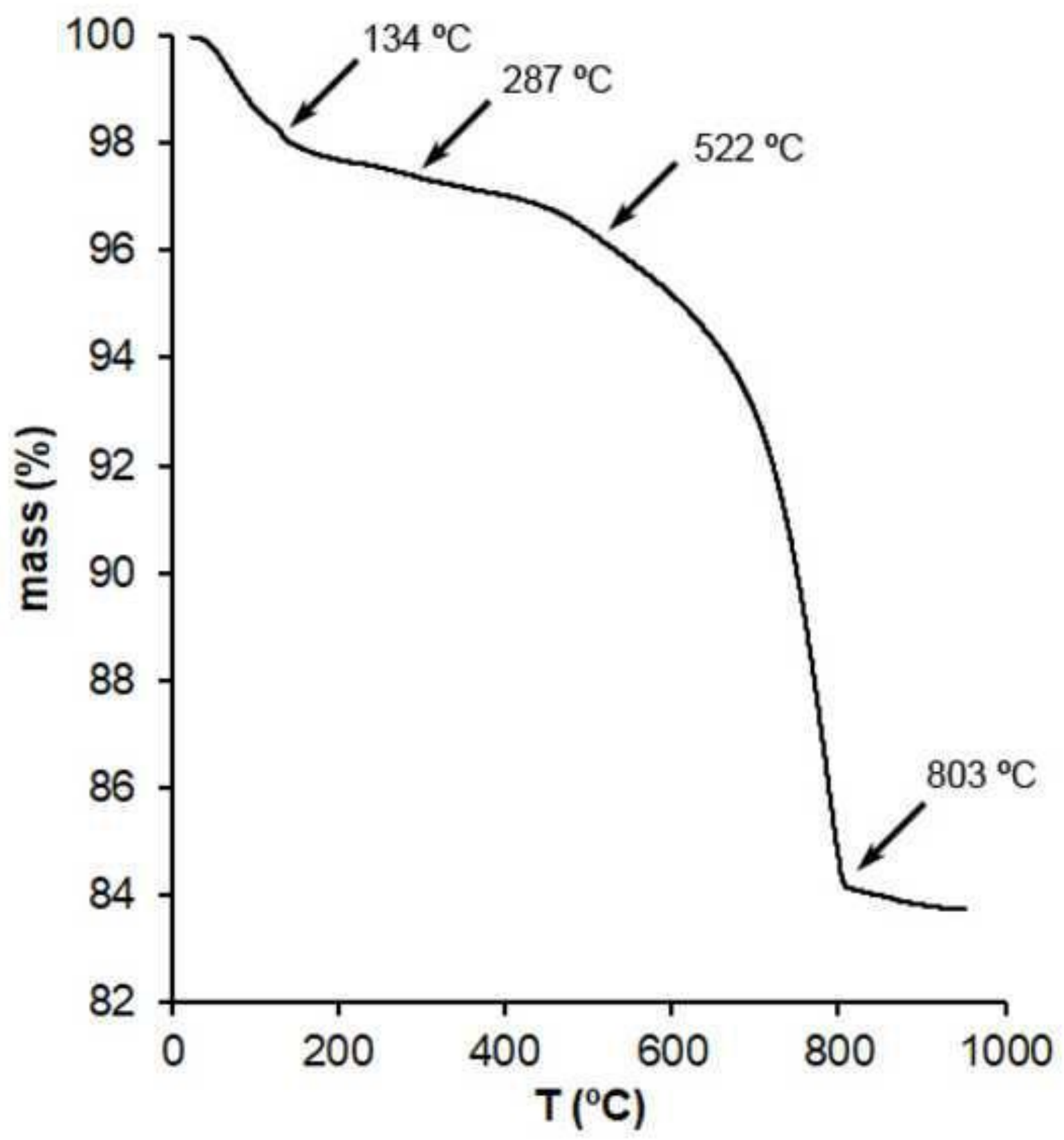

Figure 2. Thermogravimetric analysis of raw material from Jun. Temperature (in ${ }^{\circ} \mathrm{C}$ ) versus weight loss (in \%). 

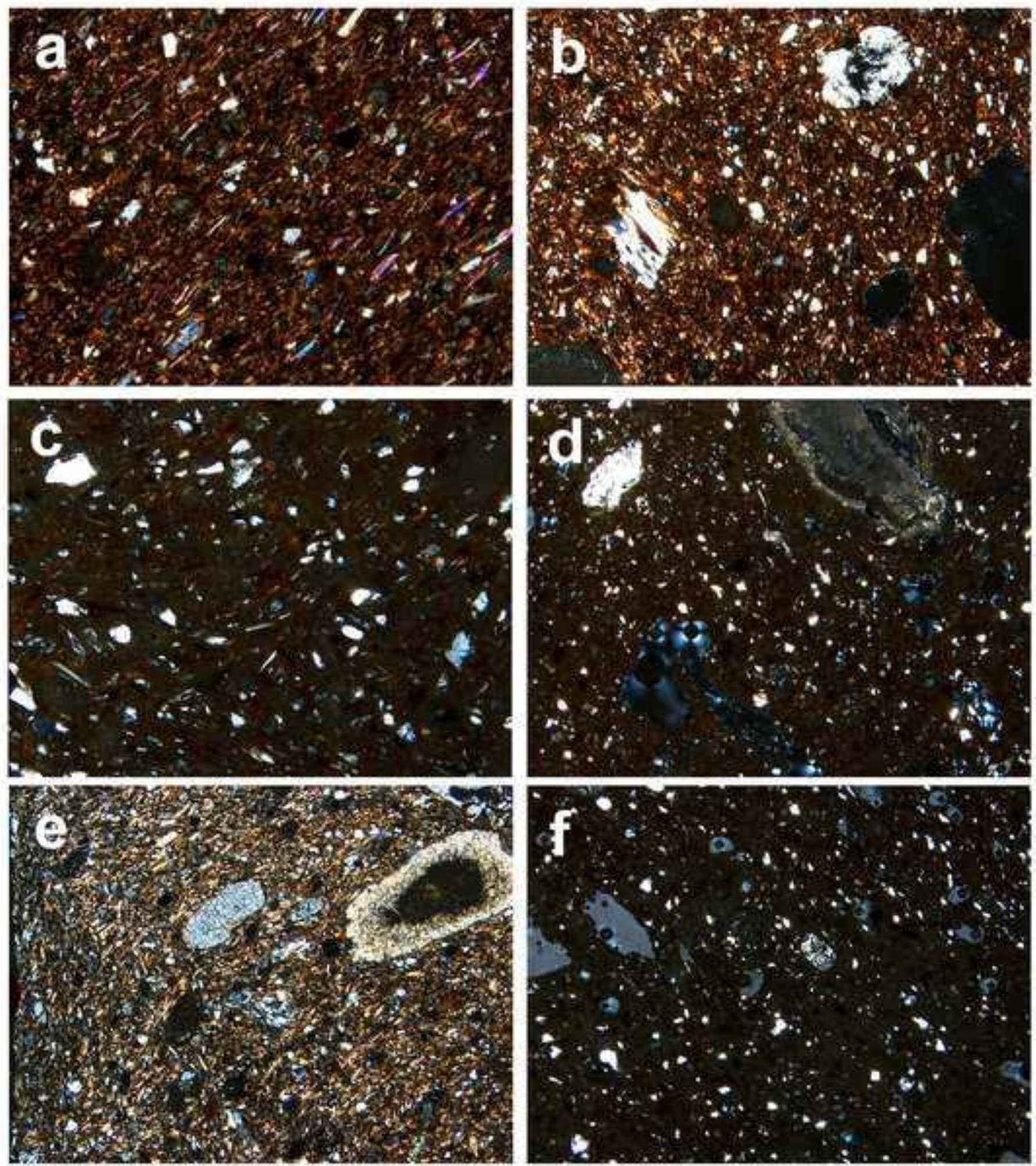

Figura 3. a) muestra J800 en la que se observa la orientación de filosilicatos debido al aplastamiento de la masa arcillosa durante la preparación de las piezas crudas. Destaca la birrefringencia de los filosilicatos que alcanza el azul de II orden; b) muestra J950 en la cual los filosilicatos han perdido la birrefringencia que se observaba a $800{ }^{\circ} \mathrm{C}$. En el sector noreste de la imagen se puede observar un grano de anhidrita fracturado; c) imagen de detalle de la muestra J1100 cuya matriz está vitrificada. Se reconocen únicamente cristales de cuarzo redondeados y algunas láminas blanquecinas de pseudomorfos de filosilicatos; d) muestra JD1100 que presenta la matriz vitrificada. Se observa un antiguo grano de carbonato de aproximadamente $1 \mathrm{~mm}$ de tamaño que se encuentra totalmente descompuesto; e) muestra JS800 caracterizada por una matriz de color más claro respecto a la muestra J800; se aprecia el menor grado de birrefringencia alcanzado por los filosilicatos. En el sector noreste de la imagen se reconoce un grano de carbonato descompuesto; f) muestra JS1100 cuya matriz está totalmente vitrificada. Se reconocen únicamente unos pequeños granos de cuarzo y los poros tienen morfología redondeada. 

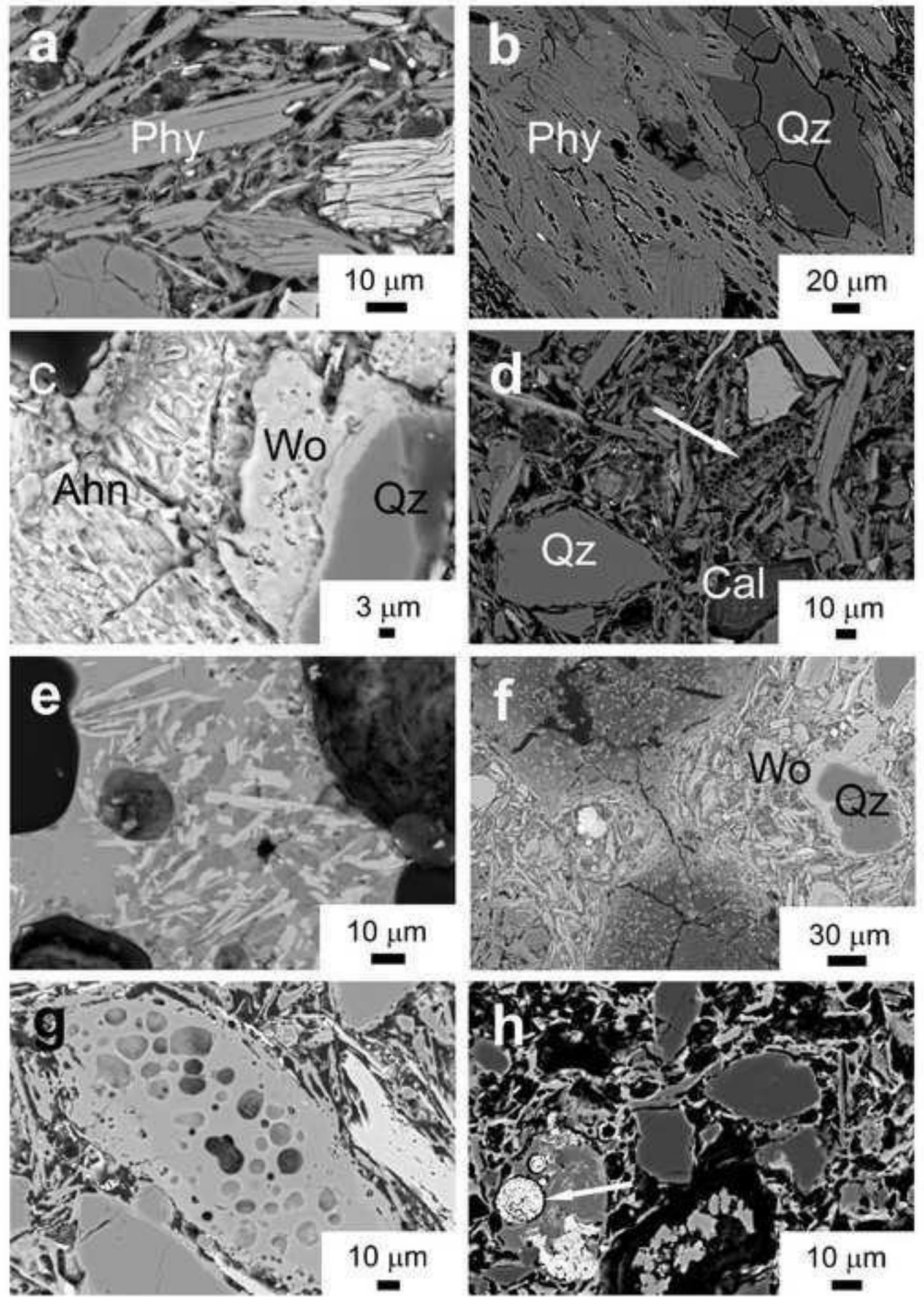

Figura 4. Imágenes de electrones retrodispersados de las muestras de Jun: a) ladrillos sin aditivos cocidos a $800{ }^{\circ} \mathrm{C}$ en el que los filosilicatos están parcialmente orientados y muestran separaciones a lo largo de los planos (001); b) ladrillo sin aditivos cocido a $950^{\circ} \mathrm{C}$. Se observa el desarrollo de burbujas ovaladas en áreas de fusión de los filosilicatos; c) ladrillo sin aditivos cocido a $1100{ }^{\circ} \mathrm{C}$ que muestra la formación de wollastonita por reacción entre cuarzo y anhidrita; d) ladrillo con lodo de diatomita calcinada cocido a $800^{\circ} \mathrm{C}$. Se reconocen fragmentos de diatomea (flecha blanca) y un grano de calcita que muestra un borde externo más oscuro indicando su parcial descomposición; e) ladrillo con lodo de diatomita calcinada cocido a 1100 ${ }^{\circ} \mathrm{C}$ en el cual se han identificado cristales aciculares de wollastonita; f) ladrillo con halita cocido a $800{ }^{\circ} \mathrm{C}$ con un importante desarrollo de cristales de wollastonita. Las zonas más oscuras corresponden a granos de carbonatos descompuestos; g) ladrillo con halita cocido a $1100{ }^{\circ} \mathrm{C}$. Se reconoce una zona de la matriz que está totalmente fundida; h) ladrillo sin aditivos cocido a $950{ }^{\circ} \mathrm{C}$ en el que se observa un cristal rico en Fe con morfología framboidal (flecha blanca). Leyenda: Phy = filosilicatos; Qz = cuarzo; Wo = wollastonita; Ahn = anhidrita; Cal = calcita. Abreviación de las fases minerales por Whitney y Evans (2010). 

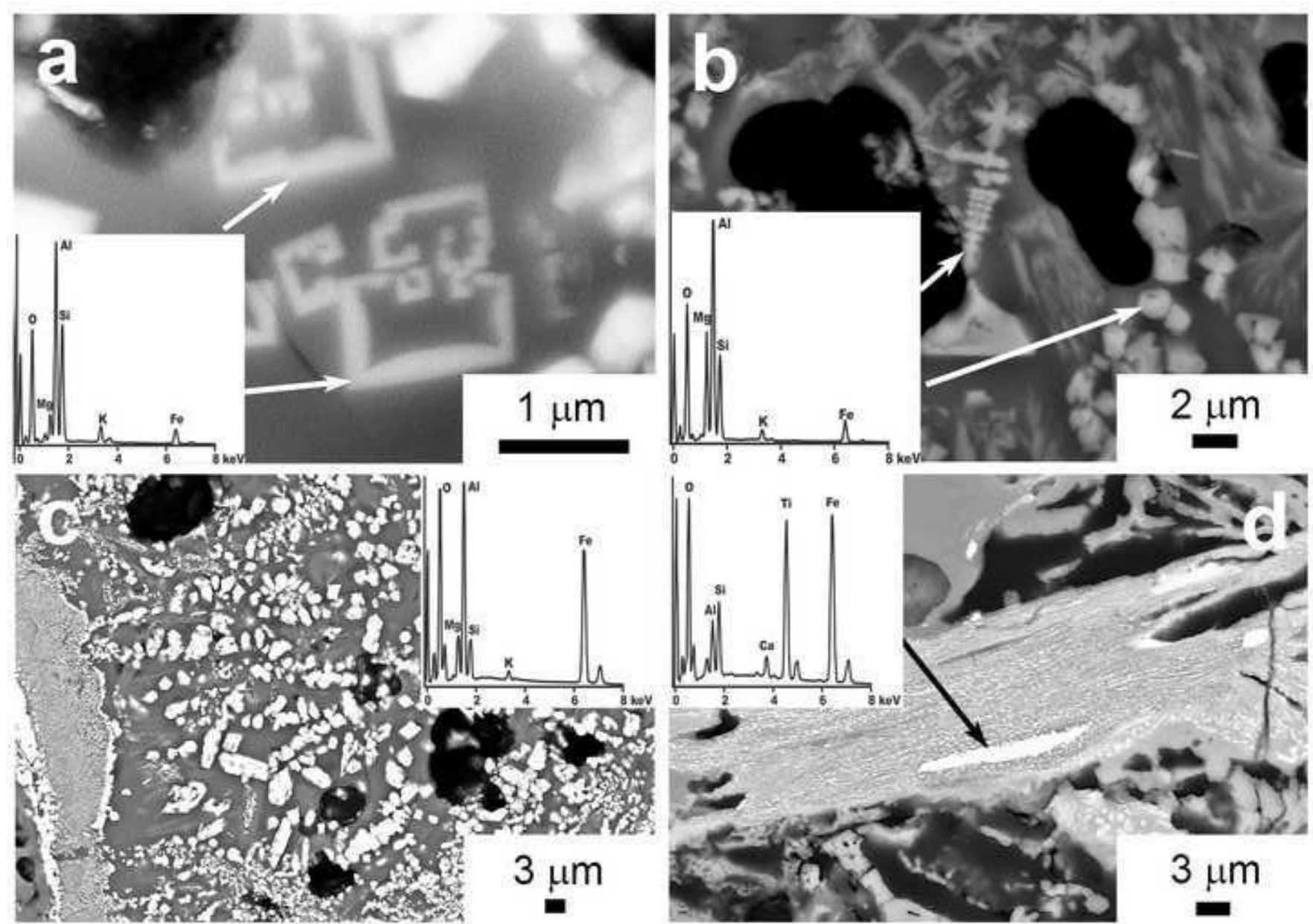

Figure 5. Detailed BSE images and EDX analysis to identify the presence of new mineral phases: a) mullite crystals with skeletal morphology in bricks without additives and fired at $950^{\circ} \mathrm{C}$; b) cordierite with dendritic morphology in bricks without additives and fired at $950{ }^{\circ} \mathrm{C}$; c) hercynite grains in bricks with halite and fired at $1100{ }^{\circ} \mathrm{C}$. Note the different size of crystals in the center of the figure and in the left corner; d) development of ilmenite crystal inside a phyllosilicate in a brick without additives fired at $1100^{\circ} \mathrm{C}$. See the growth of hematite along the sheets of the partially melted phyillosilicate. 


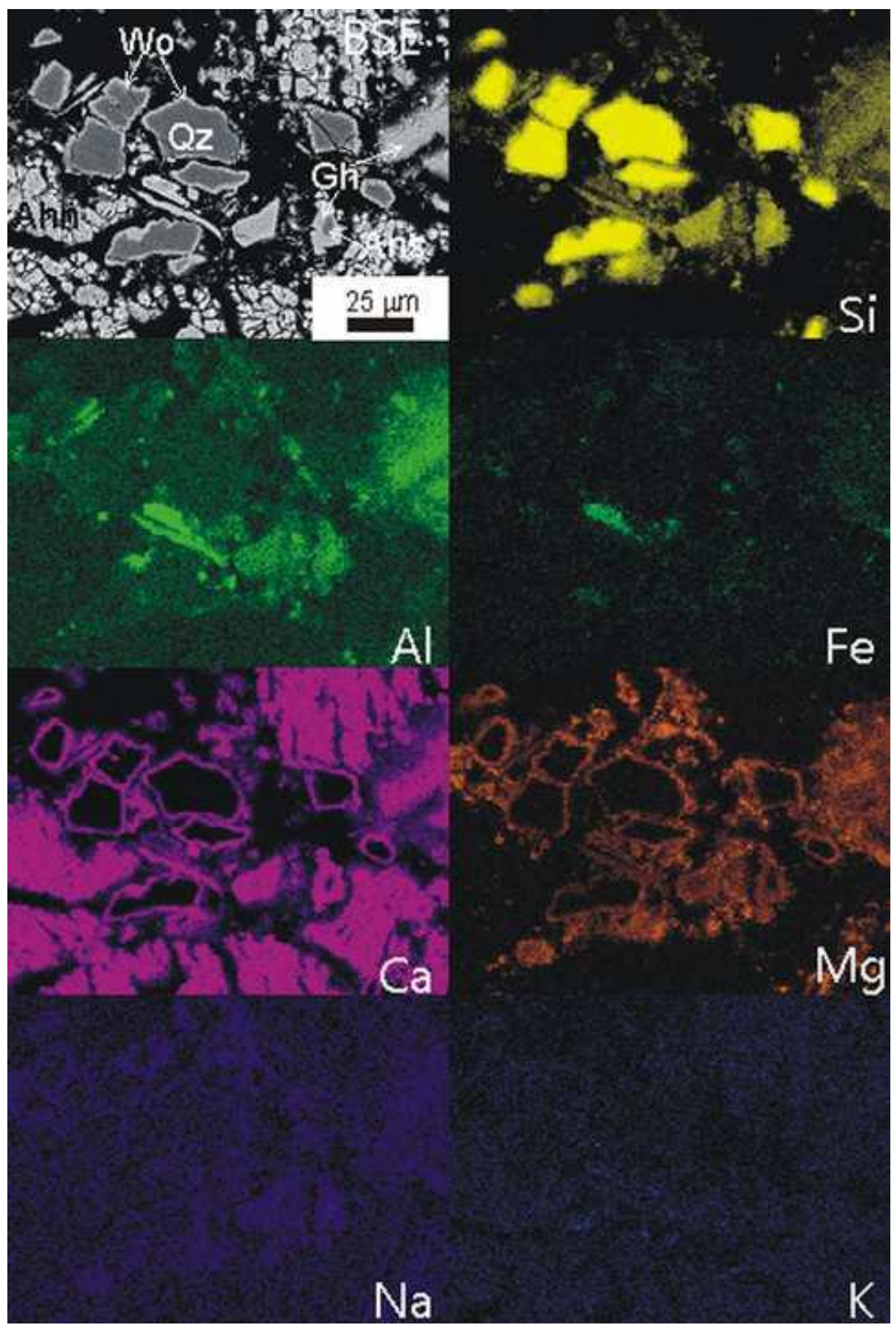

Figure 6. BSE and X-ray images of an area where silicate grains are in contact with anhadrite, and reaction coronas of Mg-wollastonite and gehlenite-an in silicates are developed. La muestra corresponde a un ladrillo sin aditivos cocido a 1100 ․ C. Leyenda: Qz = cuarzo; Wo = wollastonita; Ahn = anhidrita; Gh = gehleniteakermanite-; $A n=$ plagioclase (andesine). Abreviación de las fases minerales por Whitney y Evans (2010). 